\title{
Ekonomska ocjena investicije podizanja nasada maslina na kršu. Rezultati istraživanja melioracije (25 ha) terena u općini Tisno (Girića rat)
}

Economic evaluation of investment in new olive orchard (25 ha) in the karst. Research results of recultivation of the karst in the district of Tisno (Girića rat)

\author{
M. Čagalj, F. Strikić
}

\section{SAŽETAK}

Radi povećanja proizvodnih površina, u nedostatku obradivih poljoprivrednih površina u obalnom dijelu RH, sve više su se počeli krški tereni privoditi (melioracijom i kultivacijom) u poljoprivredna obradiva tla za intenzivne uzgoje. Kultivacija krša podrazumijeva financijski zahtjevne zahvate za pripremu tla pogodnog za uzgoj poljoprivrednih kultura, kao što su čišćenje i uklanjanje nadzemne vegetacije, niveliranje terena, ripanje ili pikamiranje, rigolanje, te mljevenje i sitnjenje kamena. S obzirom da je priprema krškog terena prvi korak i osnovni preduvjet za uspješnu realizaciju podizanja nasada maslina, te ujedno $\mathrm{i}$ financijski najveći izdatak $\mathrm{u}$ investicijskim troškovima, u tom kontekstu cilj rada je napraviti analizu ocjene ekonomske opravdanosti i financijske izvodljivosti ulaganja. Modelnom kalkulacijom utvrđeni investicijski i proizvodni troškovi, te prihodi predstavljali su ulazne parametre za financijski dio cost-benefit analize, analize osjetljivosti investicije, te ekonomsku analizu mjerila poslovne uspješnosti. Dobiveni rezultati analize investicije pokazuju da je investicija podizanja 25 ha maslinika na kršu ekonomski i financijski izvodljiva, te efikasna, uz uvjet ostvarivanja očekivanih uroda i trženja maslinovog ulja.

Ključne riječi: maslinarstvo, krš, melioracija, investicija, ekonomska opravdanost

\begin{abstract}
To increase the production areas, and because of the lack of arable agricultural land in the coastal part of Croatia, karst terrains are increasingly being turned into agricultural arable land for intensive farming and cultivation by melioration. Cultivation and melioration of karst are financially demanding projects for adapting soil to be suitable for growing crops, such as cleaning and removal of overhead vegetation, leveling the terrain, scarifying, plowing, and grinding stones and rocks. Since the first
\end{abstract}


M. Čagalj i F. Strikić: Ekonomska ocjena investicije podizanja nasada maslina na kršu. Rezultati istraživanja melioracije ( 25 ha) terena u općini Tisno (Girića rat)

step in preparation of karst terrain and the basic prerequisite for the successful raising of the newly planted olive trees represents the biggest outlay in investment costs, in this context the goal of this paper is to analyze and assess economic and financial feasibility of investments. A model calculation has identified investment and production costs and revenues that represent the input parameters for the economic cost-benefit analysis, sensitivity analysis of the investment and economic analysis of the measure of business success. The results of analysis of the investment indicate that investment to raise 25 hectares of olive trees on karst is economically and financially viable and effective, under the assumption of expected yields provided and marketing of olive oil.

Key words: olive growing, karst, melioration, investment, economic profitability

\section{UVOD}

Tradicionalni uzgoj masline u Dalmaciji ima vjekovnu tradiciju. Ova voćna vrsta bila je vjekovna "hraniteljica" lokalnog stanovništva, omogućivši održanje i razvoj stanovništva na krškim područjima obalnog i otočnog dijela Republike Hrvatske (RH). Uzgoj masline zastupljen je u cijelom obalnom i otočnom prostoru RH. Današnja razina proizvodnje (stolnih maslina i maslinova ulja) ne zadovoljava potrebe domaćeg tržišta, te se najveći dio maslinovog ulja i uvozi u RH. Prema raspoloživim službenim podacima u 2015. godini se u RH maslina uzgajala na površini od 19.100 ha (DZS, 2015), od čega 1.981 ha navodnjavanjem, a 17.119 ha bez navodnjavanja (IOC, 2015). Maslina se najviše uzgaja kao tržišno orijentirana proizvodnja na manjim ili većim obiteljskim gospodarstvima. Glavnina proizvodnje ploda masline koristi se za preradu u ulje, a godišnja proizvodnja maslinovog ulja u RH kreće se od 4.5 do 7.1 tisuća tona (DZS, 2015) što ne zadovoljava domaće potrebe za ovim proizvodom te se svake godine uvozi od 2.0 do 6.0 tisuća tona maslinovog ulja (IOC, 2015).

Maslina se uzgaja na cijelom uzgojnom području jednakim intenzitetom. Prateći globalni trend povećanja konzumacije „zdravih“ namirnica, u što se maslinovo ulje svakako ubraja, i u RH kroz proteklo desetljeće prevladava trend povećanja proizvodnje, no u zadnjih dvadeset godina povećan je interes za podizanjem novih nasada, obnovu starih maslinika, modernizaciju, povećavanje preradbenih kapaciteta uz poboljšanje kvalitete maslinovog ulja (Gugić i Ivanišević, 2011.).

Unatoč, povećanju proizvodnje u maslinarstvu još uvijek većim dijelom prevladava tradicionalan način uzgoja, kojega karakterizira neredovita rodnost. Prosječni prinosi u RH u maslinarstvu su u prosjeku od $0,5 \mathrm{t} / \mathrm{ha}$ do $2,8 \mathrm{t} / \mathrm{ha}$. Uz tradicionalan način proizvodnje, za neredovite i varijabilne prinose zaslužna 
su i klimatska obilježja u sezoni uzgoja, te sezonska najezda (epidemija) štetočinja u nasadima. Također, na maslinarskom tržištu u RH prevladava neorganiziranost, kao i uvozna ovisnost (Gugić i sur., 2010.).

Povećanjem proizvodnih površina, te u nedostatku obradivih poljoprivrednih površina u obalnom dijelu $\mathrm{RH}$, sve više su se počeli krški tereni privoditi (melioracijom i kultivacijom) u poljoprivredna obradiva tla za intenzivne uzgoje. Krš karakterizira visoka skeletnost tla (više od $50 \%$ skeleta), najčešće obrasla degradiranom makijom i slabom šumskom vegetacijom. Kultivacija krša podrazumijeva financijski zahtjevne zahvate za pripremu tla pogodnog za uzgoj poljoprivrednih kultura, kao što su čišćenje i uklanjanje nadzemne vegetacije, niveliranje terena, riperovanje ili pikamiranje, rigolanje, te mljevenje i sitnjenje kamena. S obzirom da je priprema krškog terena prvi korak i osnovni preduvjet za uspješnu realizaciju podizanja nasada maslina, ona predstavlja čitav niz zahvata i potrebnih aktivnosti koje za konačni cilj imaju stvaranje najboljih uvjeta za nesmetan rast $i$ razvoj maslina tijekom eksploatacije (Sito i sur., 2012.).

Područje Girića rat nalazi se u Šibensko-kninskoj županiji i administrativno pripada općini Tisno i smješteno je $1.7 \mathrm{~km}$ sjeverozapadno od samog mjesta Tisno, a tla spadaju u klasu kamenjara koja se vlaže oborinskim vodama, te se uglavnom klasificiraju kao crvenica na razvijenim dolomitima i vapnencima. Osnovna obilježja ovog tipa tala su veliki udio kamena u sloju od $1 \mathrm{~m}$ dubine. Prema utvrđenim pedološkim analizama u ovom sloju zemljišta nalazi se do $60 \%$ krupnog kamena dok je udio sitnice oko $40 \%$ od ukupnog volumena profila. Kako bi predmetno zemljište bilo pogodno za uzgoj masline i smokve potrebno je obaviti pripremu tla što podrazumijeva i ripanje ili pikamiranje te mljevenje (frezanje) kamena specijalnim frezama za kamen. Nakon provedene analize agroekoloških uvjeta uzgoja, zaključili smo kako oni nisu ograničavajući čimbenik za intenzivan uzgoj masline na predmetnoj lokaciji.

\section{MATERIJAL I METODE}

U radu je za potrebe troškovne analize i ocjenu tehnoloških parametara sastavljen deterministički tehnološko-ekonomski model podizanja novog nasada na kršu i proizvodnje maslina. Rezultati primijenjenog modela su kalkulacije investicijskih i proizvodnih troškova s dijelom pripadajućih fiksnih troškova (Gugić i Grgić, 2005.). Dobiveni rezultati su predstavljali ulazne parametre za financijski dio analize troškova i koristi da bi se ocijenila ekonomska opravdanost i financijska izvodljivost ulaganja u podizanje novog nasada maslina na kršu (Gugić i Ivanišević, 2011.). Metoda ekonomske analize 
temeljnih mjerila poslovne uspješnosti, kao što su proizvodnost, ekonomičnost $\mathrm{i}$ rentabilnost (Jelavić i sur., 1993.) korištena je za analizu i ocjenu efikasnosti podizanja novog maslinika i proizvodnje maslina. Svi izračuni u radu napravljeni su u kompjutorskom tabličnom programu MS Excel 2010.

Kao izvor podataka u radu su korišteni empirijski podaci i iskustva iz proizvodne prakse, normativi utroška potrebnog materijala i ljudskog i strojnog rada bazirani na odgovarajućim tehnološkim standardima, tekuće cijene na domaćem tržištu poljoprivrednih inputa i outputa, te službene statističke publikacije.

Polazišta za izradu tehnološko-ekonomskog modela su:

- Kultiviranje krškog terena za podizanje maslinika: uklanjanje postojeće vegetacije, ripanje, mljevenje, ravnanje

- Mehanizacija za kultiviranje: za pripremu terena, sadnju i iskop akumulacije unajmljena

- Sadnja: gustoća sklopa, kolčenje redova i obilježavanje sadnih mjesta, kopanje i priprema sadnih rupa, priprema sadnica i izbor sorte, vrijeme sadnje

- Površina maslinika: 25 ha

- Proizvodno usmjerenje: proizvodnja maslina isključivo za preradu u ulje

- Način uzgoja: intenzivan uzgoj

- Broj stabala za sadnju: 7.500 maslina

- Razmak sadnje: 6,0 x 5,0 m

- Uzgojni oblik: kotlasta krošnja (vaza)

- Razdoblje podizanja maslinika: 2 godine

- Razdoblje korištenja maslinika: 40 godina

- Početak rodnosti: 3 godine

- Puna rodnost: od sedme do četrdeset pete

- Sustav navodnjavanja: sustav mikroraspršivača

- Izvor vode za navodnjavanje: izgradnja akumulacije $\left(4.500 \mathrm{~m}^{3}\right)$

- Proizvodni sustav: integrirana proizvodnja

- Asortiman: Oblica 30\%, Leccino 30\%, Drobnica 10\%, Levantinka 20\% i Pendolino $10 \%$

- Ograđivanje nasada

- Način berbe: ručno i strojno (nakon sedme godine)

- Nabavna cijena maslina za sadnju: kn/kom

- Prosječan randman za proizvodnju maslinovog ulja: $16 \%$

- Prosječna prodajna cijena maslinovog ulja: kn/l 
Za obavljanje mehaniziranih radnih operacija u nasadu masline, sukladno prethodno opisanim tehničko-tehnološkim rješenjima planirana je kupovina sljedeće poljoprivredne mehanizacije s priključcima:

- traktor $2 \mathrm{kom}$.

- freza s hidrauličnim bočnim pomakom (ili vibrokultivator) 1 kom.

- podrivač s deponatorom gnojiva $1 \mathrm{kom}$.

- kardan $1 \mathrm{kom}$.

- atomizer $1 \mathrm{kom}$.

- pomična ruda za priključenje stroja na poluge traktora 1 kom.

- kardan s homokinetičkim zglobom 1 kom.

- prikolica 2 kom.

U sedmoj godini nakon sadnje predviđena je i nabava mehaničkog tresača s pogonom od priključnog vratila traktora za mehaniziranu berbu maslina.

$\mathrm{S}$ obzirom da je nasad masline i smokve udaljen oko $2 \mathrm{~km}$ od naselja Tisno na objektu će se organizirati gospodarsko dvorište. Gospodarsko dvorište sastojat će se od upravno-gospodarskog objekta, površine od oko $150 \mathrm{~m}^{2}$. Ovaj prostor će služiti radnicima koji rade u nasadu. Također treba izgraditi garažu i skladište, minimalne površine $300 \mathrm{~m}^{2}$, za smještaj poljoprivredne mehanizacije, alata i mineralnih gnojiva te sredstava za zaštitu bilja.

Za redovito održavanje nasada planirano je zaposlenje 10 radnika od čega će biti jedan inženjer poljoprivrede i dva poljoprivredna tehničara voćarsko vinogradarskog smjera. Osim stalno zaposlenih radnika Investitor će u sezoni rezidbe maslina i berbe ploda angažirati sezonsku radnu snagu. Radi kvalitetnijeg vođenja nasada preporuča se Investitoru angažman jedne konzultantske tvrtke za vođenje projekta i budućeg nasada putem Ugovora o poslovnoj suradnji.

\section{REZULTATI I RASPRAVA}

U ekonomsko-financijskom modelu, prirod ploda maslina je kalkuliran kao produkt priroda po stablu, umnožen s brojem stabala po 1 ha, dok je proizvodnja ekstra djevičanskog maslinovog ulja kalkulirana uz pretpostavljeni randman od $16 \%$. Prvi značajniji prinos od početka rodnosti u trećoj godini se postepeno povećava do sedme godine od podizanja nasada, što je i prva godina pune rodnosti.

Podizanje novog maslinika na kršu podrazumijeva dvogodišnje razdoblje bez rodnosti, odnosno razdoblje dok još nema prihoda od prodaje maslinovog ulja. U ovom razdoblju jedini prihodi su od državnih poticajnih sredstava, koja iznose $600.000,00$ kn godišnje. Također, tijekom ovog dvogodišnjeg razdoblja, 
M. Čagalj i F. Strikić: Ekonomska ocjena investicije podizanja nasada maslina na kršu. Rezultati istraživanja melioracije ( 25 ha) terena u općini Tisno (Girića rat)

postoje troškovi održavanja i njege nasada (gnojidba, suzbijanje korova i štetočinja, rezidba). Model integrirane proizvodnje plodova maslina obuhvaća vremensko razdoblje od rodnosti (treća godina, do pune rodnosti u sedmoj i idućim godinama), a sastoji se od rezdibe (zimske i ljetne), njege nasada (gnojidbe, zaštite od bolesti i štetočinja), berbe (ručna, u sedmoj godini planirana nabavka strojnog tresaća), transporta plodova u uljaru s uračunatim utovarom $\mathrm{i}$ istovarom.

U modelu je pretpostavljena prodaja ekstra djevičanskog maslinovog ulja po cijeni od 78,82 kn/1 što je prosječna proizvođačka cijena maslinovog ulja u RH u 2015. godini (DZS, 2015). Prihod od prodaje ulja izračunat je kao umnožak ukupne proizvedene količine ulja i prosječne prodajne cijene. Pretpostavka za ovakav izračun je postizanje očekivanog priroda ploda, randmana ulja $(16 \%)$ i njegove uspješne prodaje. Ukupni prihod od maslinarske proizvodnje u modelu je kalkuliran kao suma prihoda od prodaje proizvedenog maslinovog ulja i prihoda od poticaja (Tablica 1). Od sedme godine (pune rodnosti) u strukturi ukupnih prihoda od prodaje ekstra djevičanskog maslinovog ulja ostvaruje se $82.6 \%$ prihoda, a $17.4 \%$ prihoda ostvaruje se od državnih poticaja.

Tablica 1. : Izračuni ukupnih prihoda od proizvodnje maslinika na 25 ha

Table 1: Calculation of total revnues of olive grove production at 25 ha

\begin{tabular}{|c|c|c|c|c|c|c|}
\hline \multirow{2}{*}{$\begin{array}{l}\text { Ukupna } \\
\text { proizvodnja i } \\
\text { prihodi } \\
\text { Total production } \\
\text { and revenues }\end{array}$} & \multicolumn{6}{|c|}{ Godine- Years } \\
\hline & 3. & 4. & 5. & 6. & 7. & 8. - 40 . \\
\hline $\begin{array}{l}\text { Prirod ploda } \\
\text { masline (kg) } \\
\text { Yield (kg) }\end{array}$ & $22.500,00$ & $60.000,00$ & $112.500,00$ & $187.500,00$ & $225.000,00$ & $225.000,00$ \\
\hline $\begin{array}{l}\text { Proizvodnja } \\
\text { maslinovog ulja (I) } \\
\text { Olive oil production } \\
\text { (I) }\end{array}$ & $3.600,00$ & $9.600,00$ & $18.000,00$ & $30.000,00$ & $36.000,00$ & $36.000,00$ \\
\hline $\begin{array}{l}\text { Vrijednost od } \\
\text { prodaje maslinovog } \\
\text { ulja (kn) } \\
\text { Olive oil revenue } \\
\text { (HRK) }\end{array}$ & $283.752,00$ & $756.672,00$ & $1.418 .760,00$ & $2.364 .600,00$ & $2.837 .520,00$ & $2.837 .520,00$ \\
\hline $\begin{array}{l}\text { Državna poticajna } \\
\text { sredstva (kn) } \\
\text { Subsidy revenue } \\
\text { (HRK) }\end{array}$ & $600.000,00$ & $600.000,00$ & $600.000,00$ & $600.000,00$ & $600.000,00$ & $600.000,00$ \\
\hline $\begin{array}{l}\text { Ukupno (kn) } \\
\text { Total (HRK) }\end{array}$ & $883.752,00$ & $1.356 .672,00$ & $2.018 .760,00$ & $2.964 .600,00$ & $3.437 .520,00$ & $3.437 .520,00$ \\
\hline
\end{tabular}

Ukupni investicijski troškovi podizanja nasada maslina na kršu u površini od 25 ha u modelu obuhvaćaju i dvogodišnje razdoblje bez prinosa. Ukupna vrijednost investicijskog ulaganja iznosi 6.705.217,75 kn (Tablica 2). 
M. Čagalj i F. Strikić: Ekonomska ocjena investicije podizanja nasada maslina na kršu. Rezultati istraživanja melioracije ( $25 \mathrm{ha}$ ) terena u općini Tisno (Girića rat)

Tablica 2.: Modelna kalkulacija investicijskih troškova podizanja nasada 25 ha maslina.

Table 2: Model-calculated investment costs for the 2 ha olive grove establishment.

\begin{tabular}{|c|c|c|c|}
\hline \multirow{2}{*}{$\begin{array}{l}\text { Vrsta troškova } \\
\text { Type of costs }\end{array}$} & $\begin{array}{c}\text { 1. godina } \\
1^{\text {st }} \text { year }\end{array}$ & $\begin{array}{l}\text { 2. godina } \\
2^{\text {nd }} \text { year }\end{array}$ & $\begin{array}{l}\text { 3.godina } \\
3^{\text {rd }} \text { year }\end{array}$ \\
\hline & $\begin{array}{c}\text { Iznos (kn) } \\
\text { Value (HRK) }\end{array}$ & $\begin{array}{c}\text { Iznos (kn) } \\
\text { Value (HRK) }\end{array}$ & $\begin{array}{c}\text { Iznos (kn) } \\
\text { Value (HRK) }\end{array}$ \\
\hline \multicolumn{4}{|l|}{ 1. Materijal-Material } \\
\hline $\begin{array}{l}\text { Stajsko gnojivo } \\
\text { Manure }\end{array}$ & $252.000,00$ & 0,00 & 0,00 \\
\hline $\begin{array}{l}\text { Mineralno gnojivo (NPK) } \\
\text { Mineral fertilizer (NPK) }\end{array}$ & $396.900,00$ & $145.530,00$ & $145.530,00$ \\
\hline $\begin{array}{l}\text { Mineralno gnojivo (KAN) } \\
\text { Mineral fertilizer (KAN) }\end{array}$ & $43.560,00$ & $59.895,00$ & $59.895,00$ \\
\hline $\begin{array}{l}\text { Sadnice masline Levantinka } \\
\text { Planting Levantinka }\end{array}$ & $120.000,00$ & $12.000,00$ & 0,00 \\
\hline $\begin{array}{l}\text { Sadnice maslina ostale sorte } \\
\text { Planting olives other }\end{array}$ & $189.000,00$ & $18.900,00$ & 0,00 \\
\hline $\begin{array}{l}\text { Kolci } \\
\text { Pickets }\end{array}$ & $165.000,00$ & 0,00 & 0,00 \\
\hline $\begin{array}{l}\text { Vezivo } \\
\text { Solder }\end{array}$ & 650,00 & 260,00 & 0,00 \\
\hline $\begin{array}{l}\text { Sredstva za zaštitu bilja } \\
\text { Pest management }\end{array}$ & $18.750,00$ & $18.750,00$ & $18.750,00$ \\
\hline $\begin{array}{l}\text { Sredstva za dezin. sadnih mj. } \\
\text { Desinfection of planting place }\end{array}$ & $82.500,00$ & $8.250,00$ & 0,00 \\
\hline $\begin{array}{l}\text { Ostalo } \\
\text { Other }\end{array}$ & $50.000,00$ & $33.333,00$ & $25.000,00$ \\
\hline Ukupno materijal & 1.318.360,00 & $296.918,00$ & $249.175,00$ \\
\hline \multicolumn{4}{|l|}{ 2. Rad strojeva } \\
\hline $\begin{array}{l}\text { Vadenje panjeva prethodne vegetacije } \\
\text { Exctracting stumps }\end{array}$ & $444.000,00$ & 0,00 & 0,00 \\
\hline $\begin{array}{l}\text { Ripanje, pikamiranje i mljevenje } \\
\text { kamena } \\
\text { Rippening }\end{array}$ & $2.750 .000,00$ & 0,00 & 0,00 \\
\hline $\begin{array}{l}\text { Ravnanje terena } \\
\text { Grading }\end{array}$ & $50.000,00$ & 0,00 & 0,00 \\
\hline $\begin{array}{l}\text { Kopanje sadnih mjesta } \\
\text { Digging of planting space }\end{array}$ & $60.000,00$ & $10.000,00$ & 0,00 \\
\hline $\begin{array}{l}\text { Dovoz mineralnog gnojiva i gnojidba } \\
\text { Transportation of fertilizers }\end{array}$ & $70.000,00$ & $20.000,00$ & $20.000,00$ \\
\hline $\begin{array}{l}\text { Dovoz stajskog gnojiva i gnojidba } \\
\text { Transportation of manure }\end{array}$ & $70.000,00$ & 0,00 & 0,00 \\
\hline $\begin{array}{l}\text { Dovoz sadnica } \\
\text { Transportation of seedlings }\end{array}$ & $20.000,00$ & $2.000,00$ & 0,00 \\
\hline $\begin{array}{l}\text { Jesensko i proljetno oranje } \\
\text { Tillage in autumn and spring }\end{array}$ & $80.000,00$ & $80.000,00$ & $80.000,00$ \\
\hline $\begin{array}{l}\text { Kultivacija } 4 \mathrm{x} \\
\text { Cultivation }\end{array}$ & $120.000,00$ & $120.000,00$ & $120.000,00$ \\
\hline $\begin{array}{l}\text { Zaštita } \\
\text { Protection }\end{array}$ & $40.000,00$ & $40.000,00$ & $40.000,00$ \\
\hline $\begin{array}{l}\text { Ostalo } \\
\text { Others }\end{array}$ & $100.000,00$ & $35.000,00$ & $35.000,00$ \\
\hline $\begin{array}{l}\text { Ukupno rad strojeva } \\
\text { Total machine work }\end{array}$ & $3.804 .000,00$ & $307.000,00$ & $295.000,00$ \\
\hline \multicolumn{4}{|l|}{$\begin{array}{l}\text { 3. Ljudski rad } \\
\text { Human labour }\end{array}$} \\
\hline $\begin{array}{l}\text { Sječa postojeće vegetacije } \\
\text { Cutting existing vegetation }\end{array}$ & $169.296,50$ & 0,00 & 0,00 \\
\hline $\begin{array}{l}\text { Sakupljanje ostataka korijena } \\
\text { Roots collecting }\end{array}$ & $5.470,00$ & 0,00 & 0,00 \\
\hline $\begin{array}{l}\text { Kolčenje sadnih mjesta } \\
\text { Picketing }\end{array}$ & $21.880,00$ & 0,00 & 0,00 \\
\hline $\begin{array}{l}\text { Ispunjavanje sadnih rupa i gnojidba } \\
\text { Fertilization }\end{array}$ & $43.760,00$ & $4.376,00$ & 0,00 \\
\hline $\begin{array}{l}\text { Dovoz i razmještaj sadnica } \\
\text { Transportation and distribution of } \\
\text { seedlings }\end{array}$ & $2.735,00$ & 273,50 & 0,00 \\
\hline
\end{tabular}


M. Čagalj i F. Strikić: Ekonomska ocjena investicije podizanja nasada maslina na kršu. Rezultati istraživanja melioracije ( $25 \mathrm{ha}$ ) terena u općini Tisno (Girića rat)

\begin{tabular}{|c|c|c|c|}
\hline $\begin{array}{l}\text { Utovar-istovar min. gnojiva i zašt. sred. } \\
\text { Loading-unloading fertilizers }\end{array}$ & $2.735,00$ & $1.367,50$ & $1.367,50$ \\
\hline Utovar-istovar stajnjaka i gnojidba & $5.470,00$ & 0,00 & 0,00 \\
\hline $\begin{array}{l}\text { Vezanje sadnica za kolac } \\
\text { Tying of seedlings for picket }\end{array}$ & $6.837,50$ & 683,75 & 0,00 \\
\hline $\begin{array}{l}\text { Rezidba (zimska) } \\
\text { Winter pruning }\end{array}$ & 0,00 & $2.735,00$ & $4.102,50$ \\
\hline $\begin{array}{l}\text { Rezidba (ljetna) } \\
\text { Summer pruning }\end{array}$ & 0,00 & $2.735,00$ & $4.102,50$ \\
\hline $\begin{array}{l}\text { Berba } \\
\text { Harvest }\end{array}$ & 0,00 & $2.735,00$ & $4.102,50$ \\
\hline $\begin{array}{l}\text { Ostalo } \\
\text { Others }\end{array}$ & $25.000,00$ & $1.500,00$ & $1.500,00$ \\
\hline $\begin{array}{l}\text { Ukupno ljudski rad } \\
\text { Total human labour }\end{array}$ & $283.184,00$ & $16.405,75$ & $15.175,00$ \\
\hline $\begin{array}{l}\text { 4. Gospodarski objekti i akumulacija } \\
\text { Buildings and accumulation }\end{array}$ & $\mathbf{0 , 0 0}$ & $666.000,00$ & 0,00 \\
\hline $\begin{array}{l}\text { 5. Osnivačka ulaganja } \\
\text { (dokumentacija, intelektualne usluge } \\
\text { i sl.) } \\
\text { Base stock }\end{array}$ & $\mathbf{0 , 0 0}$ & $100.000,00$ & $100.000,00$ \\
\hline $\begin{array}{l}\text { 6. Ugradnja sustava za } \\
\text { navodnjavanje } \\
\text { Irrigation system }\end{array}$ & $120.000,00$ & $\mathbf{0 , 0 0}$ & 0,00 \\
\hline $\begin{array}{l}\text { 7. UKUPNO (po godini) } \\
\text { Total (per year) }\end{array}$ & $5.525 .544,00$ & $720.323,75$ & $659.350,00$ \\
\hline
\end{tabular}

Iz Tablice 2 je vidljivo da ukupni troškovi u prvoj godini podizanja nasada maslina na površini od 25 ha predstavljaju 82.4\% ukupnih investicijskih troškova. Veliki postotak ukupnih investicijskih troškova u prvoj godini predstavljaju troškovi ranih operacija privođenja krškog terena u poljoprivredno tlo pogodno za sadnju maslina. Najveći pojedinačni nositelj investicijskih troškova je kultivacija tla za sadnju, s udjelom od 56,7\% u ukupnim investicijskim troškovima. U drugoj godini troškovi čine $9.3 \%$, dok u trećoj čine $8.3 \%$ ukupnih investicijskih troškova. Najvećim dijelom troškovi druge godine odnose se na kupovinu potrebne opreme i mehanizacije, a udio troškova druge $\mathrm{i}$ treće godine odnosi se na dosađivanje sadnica maslina (ukalkulirano neprimanje sadnica od $10 \%$ ), te njegu nasada u nerodnim godinama. S obzirom da je nasad masline udaljen oko $2 \mathrm{~km}$ od naselja Tisno na objektu će se organizirati gospodarsko dvorište. Gospodarsko dvorište sastojat će se od upravnogospodarskog objekta, površine oko $150 \mathrm{~m}^{2}$.

Modelnom kalkulacijom utvrđena je vrijednost ulaganja $u$ opremu, mehanizaciju i gospodarske objekte (Tablica 3). Ulaganje u opremu, mehanizaciju i izgradnju gospodarskih objekata predviđeno je u prvoj godini podizanja nasada, dok je u osmoj godini predviđeno dodatno ulaganje $u$ 
M. Čagalj i F. Strikić: Ekonomska ocjena investicije podizanja nasada maslina na kršu. Rezultati istraživanja melioracije ( $25 \mathrm{ha}$ ) terena u općini Tisno (Girića rat)

\section{Tablica 3.: Predračunska vrijednost ulaganja u opremu, mehanizaciju i gospodarske objekte}

Table 3. The estimated value of the investment in equipment, machinery and farm buildings

\begin{tabular}{|c|c|c|c|c|c|c|}
\hline \multirow{2}{*}{$\begin{array}{c}\text { Opis } \\
\text { Description }\end{array}$} & \multirow{2}{*}{$\begin{array}{c}\text { Jedinica } \\
\text { Mjere } \\
\text { Measurement } \\
\text { unit }\end{array}$} & \multirow{2}{*}{$\begin{array}{c}\text { Jedinična } \\
\text { cijena (kn) } \\
\text { Unit price } \\
\text { (HRK) }\end{array}$} & \multirow{2}{*}{$\begin{array}{c}\text { količina } \\
\text { Quantity }\end{array}$} & \multicolumn{2}{|c|}{$\begin{array}{c}\text { Nabava u } \\
\text { Purchase in }\end{array}$} & \multirow{2}{*}{$\begin{array}{l}\text { Ukupno } \\
\text { (kn) } \\
\text { Total } \\
\text { (kn) }\end{array}$} \\
\hline & & & & $\begin{array}{l}\text { godini } \\
1^{\text {st }} \text { year }\end{array}$ & $\begin{array}{l}\text { 8. godini } \\
8^{\text {th }} \text { year }\end{array}$ & \\
\hline \multicolumn{7}{|l|}{$\begin{array}{l}\text { 1.Oprema i mehanizacija } \\
\text { Equioment and mechanisation }\end{array}$} \\
\hline $\begin{array}{l}\text { Sustav za navodnjavanje } \\
\text { Irrigation system }\end{array}$ & ha & $13.000,00$ & 50 & $650.000,00$ & 0,00 & $650.000,00$ \\
\hline $\begin{array}{l}\text { Traktor } \\
\text { Tractor }\end{array}$ & kom & $238.350,00$ & 2 & $476.700,00$ & 0,00 & $476.700,00$ \\
\hline $\begin{array}{l}\text { Freza s hidrauličnim bočnim } \\
\text { pomakom } \\
\text { Thrower }\end{array}$ & kom & $37.576,00$ & 1 & $37.576,00$ & 0,00 & $37.576,00$ \\
\hline $\begin{array}{l}\text { Podrivač s deponatorm gnojiva } \\
\text { Sapper }\end{array}$ & kom & $15.900,00$ & 1 & $15.900,00$ & 0,00 & $15.900,00$ \\
\hline $\begin{array}{l}\text { Traktorska prikolica } \\
\text { Tractor trailer }\end{array}$ & kom & $39.750,00$ & 2 & $79.500,00$ & 0,00 & $79.500,00$ \\
\hline $\begin{array}{l}\text { Atomizer } \\
\text { Atomizer }\end{array}$ & kom & $38.918,00$ & 1 & $38.918,00$ & 0,00 & $38.918,00$ \\
\hline $\begin{array}{l}\text { Samohodni tresač za berbu } \\
\text { masline } \\
\text { Self proppeled shaker }\end{array}$ & kom & $400.000,00$ & 1 & 0,00 & $400.000,00$ & $400.000,00$ \\
\hline $\begin{array}{l}\text { Pneumatske škare ( } 3 \text { agregata) } \\
\text { Pneumatic scissors }\end{array}$ & kom & $10.000,00$ & 5 & $50.000,00$ & 0,00 & $50.000,00$ \\
\hline $\begin{array}{l}\text { Voćarske pile } \\
\text { Fruit saw }\end{array}$ & kom & 100,00 & 20 & $2.000,00$ & 0,00 & $2.000,00$ \\
\hline $\begin{array}{l}\text { Voćarske nožice } \\
\text { Fruit scissors }\end{array}$ & kom & 230,00 & 15 & $3.450,00$ & 0,00 & $3.450,00$ \\
\hline Ukupno oprema i mehanizacija & & & & $1.354 .044,00$ & $400.000,00$ & $1.754 .044,00$ \\
\hline \multicolumn{7}{|l|}{$\begin{array}{l}\text { 2. Gospodarski objekti } \\
\text { Economic facilities }\end{array}$} \\
\hline $\begin{array}{l}\text { Izgradnja gospodarsko upravnog } \\
\text { objekta } \\
\text { Main building }\end{array}$ & $\mathrm{m} 2$ & $1.000,00$ & 150 & $150.000,00$ & 0,00 & $150.000,00$ \\
\hline $\begin{array}{l}\text { Izgradnja akumulacije za vodu } \\
\text { Construction of water }\end{array}$ & $\mathrm{m} 3$ & & 1 & $216.000,00$ & 0,00 & $216.000,00$ \\
\hline $\begin{array}{l}\text { Izgradnja garaže i skladišta } \\
\text { (procjena) } \\
\text { Construction of garages } \\
\text { and warehouses }\end{array}$ & $\mathrm{m} 2$ & $1.000,00$ & 300 & $300.000,00$ & 0,00 & $300.000,00$ \\
\hline Ukupno gospodarski objekti & & & & $666.000,00$ & 0,00 & $666.000,00$ \\
\hline UKUPNO & & & & $2.020 .044,00$ & $400.000,00$ & $2.420 .044,00$ \\
\hline
\end{tabular}


M. Čagalj i F. Strikić: Ekonomska ocjena investicije podizanja nasada maslina na kršu. Rezultati istraživanja melioracije ( $25 \mathrm{ha}$ ) terena u općini Tisno (Girića rat)

mehanizaciju i opremu, odnosno nabavka samohodnog tresača za berbu maslina. Amortizacija osnovnih sredstava proračunata je linearnom metodom (Tablica 4). Temeljem proračunatih rezultata tehnološko-ekonomskog modela $\mathrm{i}$ primjenom dinamičkih metoda investicijskog odlučivanja, te provedenom analizom i dinamičkom ocjenom ekonomske opravdanosti i financijske izvodljivosti investicije podizanja 25 ha maslinika na kršu, rezultati sugeriraju da je razdoblje povrata investicije 7 godina. U sedmoj godini kumulativna vrijednost neto primitaka iz ekonomskog tijeka veća je od ukupne vrijednosti

\section{Tablica 4.: Proračuni amortizacije}

\section{Table 4: Calculations of depreciation}

\begin{tabular}{|c|c|c|c|c|}
\hline & $\begin{array}{l}\text { Osnovica (kn) } \\
\text { Base (HRK) }\end{array}$ & $\begin{array}{c}\text { Stopa otpisa } \\
\text { Rate of } \\
\text { depreciation }\end{array}$ & $\begin{array}{c}\text { Iznos (kn) } \\
\text { Amount (HRK) }\end{array}$ & $\begin{array}{c}\begin{array}{c}\text { Ostatak } \\
\text { vrijednosti } \\
\text { (kn) }\end{array} \\
\text { Residual value } \\
\text { (HRK) }\end{array}$ \\
\hline $\begin{array}{l}\text { A) Maslinik } \\
\text { Olive grove }\end{array}$ & $5.525 .544,00$ & $10 \%$ & $552.554,40$ & \\
\hline \multicolumn{5}{|l|}{$\begin{array}{l}\text { B) Oprema i mehanizacija } \\
\text { Equipment and mechanisation }\end{array}$} \\
\hline $\begin{array}{l}\text { Sustav za navodnjavanje } \\
\text { Irr igation system }\end{array}$ & $120.000,00$ & $10 \%$ & $12.000,00$ & \\
\hline $\begin{array}{l}\text { Traktor } \\
\text { Tractor }\end{array}$ & $476.700,00$ & $25 \%$ & $119.175,00$ & \\
\hline $\begin{array}{l}\text { Freza s hidrauličnim bočnim pomakom } \\
\text { Thrower }\end{array}$ & $37.576,00$ & $25 \%$ & $9.394,00$ & \\
\hline $\begin{array}{l}\text { Podrivač s deponatorm gnojiva } \\
\text { Sapper }\end{array}$ & $15.900,00$ & $25 \%$ & $3.975,00$ & \\
\hline $\begin{array}{l}\text { Traktorska prikolica } \\
\text { Tractor trailer }\end{array}$ & $79.500,00$ & $25 \%$ & $19.875,00$ & \\
\hline $\begin{array}{l}\text { Atomizer } \\
\text { Atomizer }\end{array}$ & $38.918,00$ & $25 \%$ & $9.729,50$ & \\
\hline $\begin{array}{l}\text { Samohodni tresač za berbu masline } \\
\text { Self-proppeled shaker }\end{array}$ & $400.000,00$ & $25 \%$ & $100.000,00$ & \\
\hline $\begin{array}{l}\text { Pneumatske škare ( } 3 \text { agregata) } \\
\text { Pneumatic scissors }\end{array}$ & $50.000,00$ & $25 \%$ & $12.500,00$ & \\
\hline $\begin{array}{l}\text { Voćarske pile } \\
\text { Fruit saw }\end{array}$ & $2.000,00$ & $25 \%$ & 500,00 & \\
\hline $\begin{array}{l}\text { Voćarske nožice } \\
\text { Fruit scissors }\end{array}$ & $3.450,00$ & $25 \%$ & 862,50 & \\
\hline \multicolumn{5}{|l|}{$\begin{array}{l}\text { C) Gospodarski objekti } \\
\text { Storage building }\end{array}$} \\
\hline $\begin{array}{l}\text { Izgradnja gospodarsko upravnog objekta } \\
\text { Main building }\end{array}$ & $450.000,00$ & $5 \%$ & $22.500,00$ & $225.000,00$ \\
\hline $\begin{array}{l}\text { Izgradnja akumulacije za vodu } \\
\text { Construction of water accumulation }\end{array}$ & $216.000,00$ & $10 \%$ & $21.600,00$ & \\
\hline $\begin{array}{l}\text { D) Osnivačka ulaganja } \\
\text { Base stock }\end{array}$ & $4.000 .000,00$ & $20 \%$ & $800.000,00$ & \\
\hline $\begin{array}{l}\text { Ukupno }(A+B+C+D) \\
\text { Total }(A+B+C+D)\end{array}$ & $11.415 .588,00$ & & $1.684 .665,40$ & \\
\hline
\end{tabular}


M. Čagalj i F. Strikić: Ekonomska ocjena investicije podizanja nasada maslina na kršu.

Rezultati istraživanja melioracije ( 25 ha) terena u općini Tisno (Girića rat)

investicije. Prema primijenjenoj metodi, investicija je prihvatljiva za ulaganje, s obzirom da je vremensko razdoblje povrata investicije unutar modelom pretpostavljenog vremenskog razdoblja. Temeljem ekonomskog tijeka, uz diskontnu stopu od 7\%, izračunata neto sadašnja vrijednost iznosi 1.025.967,28 kn. Pozitivna vrijednost neto sadašnje vrijednosti prema ovoj metodi pokazuje nam da je investicija prihvatljiva za investitora. Vrijednost interne stopa povrata je $10 \%$, a izračunata je temeljem ekonomskog tijeka postupkom interpolacije. S obzirom da je i interna stopa povrata veća od minimalno tražene diskontne stope od $7 \%$, i po ovoj metodi je investicija prihvatljiva za investitora.

Analizom osjetljivosti utvrđeno je da pri 10\%-tnom smanjenju prodajne cijene litre ekstra djevičanskog maslinovog ulja, uz nepromijenjen urod, neto sadašnja vrijednost iznosi $389.088,40 \mathrm{kn}$, interna stopa povrata je $8 \%$, a povrat investicije je u sedmoj godini ekonomskog tijeka trajanja investicije.

Analizom osjetljivosti utvrđeno je da u slučaju 10\%-tnog povećanja izdataka, uz nepromijenjen urod, neto sadašnja vrijednost iznosi 146.622,94 kn, a interna stopa povrata $7 \%$, uz povrat investicije u sedmoj godini. Rezultati obje analize osjetljivosti investicije pokazuju da je investicija osjetljiva na promjene (smanjenje prihoda $\mathrm{i}$ povećanje rashoda) te podnosi 10\%-tne promjene, ali povećanje prihoda ne smije biti veće od 13\%. Investicija je pri 10\%-tnim promjenama povećanja izdataka i smanjenja prihoda ekonomski opravdana i financijski izvodljiva za investitora, s pretpostavkom ostvarivanja očekivanih uroda, te uspješnog plasmana i prodaje ekstra djevičanskog maslinovog ulja.

$\mathrm{U}$ sedmoj godini trajanja investicije, kada maslinik ulazi u fazu pune rodnosti i punog proizvodnog kapaciteta, prikazani su ekonomski pokazatelji uspješnosti poslovanja (Tablica 5).

Tablica 5.: Ekonomski pokazatelji u punoj rodnosti maslinika (7. godina)

Table 5: Economic indicators in full production capacity $\left(7^{\text {th }}\right.$ year)

\begin{tabular}{|l|r|}
\hline $\begin{array}{l}\text { Ekonomska veličina - pokazatelj } \\
\text { / Economic indicator }\end{array}$ & $\begin{array}{c}\text { Vrijednost } \\
\text { / Value }\end{array}$ \\
\hline Ukupni prihod (kn)/ Total revenue (HRK) & $3.437 .520,00$ \\
\hline Ukupni troškovi (kn)/ Total costs (HRK) & $901.881,50$ \\
\hline Financijski rezultat (kn)/ Financial result (HRK) & $2.535 .638,50$ \\
\hline Proizvodnost rada(kn)/ Labour productivity (HRK) & 316,82 \\
\hline Ekonomičnost/ Cost- effectiveness & 3,81 \\
\hline Rentabilnost (\%)/ Profitability (\%) & 281,15 \\
\hline Cijena koštanja $(\mathrm{kn} / \mathrm{kg}) /$ Break-even price $(\mathrm{HRK} / \mathrm{kg})$ & 25,05 \\
\hline Točka pokrića $(\mathrm{kg}) /$ Break-even yield $(\mathrm{kg})$ & 11.442 \\
\hline
\end{tabular}


Financijski rezultat $\mathrm{u}$ sedmoj godini (puni prinos) trajanja investicije iznosi 2.535.638,50 kn. Vrijednosti ostalih ekonomskih pokazatelja, kao što su proizvodnost rada, ekonomičnost i rentabilnost proizvodnje pokazuju da je proizvodnja maslina i ekstra djevičanskog maslinovog ulja, uz navedene pretpostavke, efikasna i ekonomski opravdana.

\section{ZAKLJUČAK}

Ukupna vrijednost ulaganja u podizanje 25 ha maslinika melioracijom krša iznosi $6.705 .217,75 \mathrm{kn}$. Ekonomska analiza investicije pokazuje da je investicija ekonomski opravdana i financijski izvodljiva za investitora, uz navedene pretpostavke postizanja očekivanih proizvodnih i prodajnih rezultata. Pozitivan financijski rezultat maslinika površine 25 ha iznosi $2.535 .638,50 \mathrm{kn}$ pri punom urodu. Investicija je opravdana i financijski izvedljiva i pri 10\%-tnim promjenama u prihodima (smanjenja prodajne cijene) i izdacima (povećanje troškova roizvodnje), što je utvrđeno analizom osjetljivosti.

\section{LITERATURA}

DRŽAVNI ZAVOD ZA STATISTIKU (2015.): Statistički ljetopis Republike Hrvatske 2015. Zagreb, Prosinac. ISSN 1333-3305.

DRŽAVNI ZAVOD ZA STATISTIKU (2015.): Cijene u poljoprivredi u 2015. Broj: 1.1.4. ISSN 1330-0350

INTERNATIONAL OLIVE COUNCIL (2015.): EU olive oil figures.

GUGIĆ, J., IVANIŠEVIĆ, T. (2011.): Ekonomska ocjena investicije u proizvodni sustav maslina-ovca. Pomologia Croatica Vol. 17 (3-4).

GUGIĆ, J., TRATNIK, M., STRIKIĆ, F., GUGIĆ, M., KURSAN, P. (2010.): Pregled stanja i perspektiva razvoja hrvatskoga maslinarstva. Pomologia Croatica 16 (3-4), 121-146.

GUGIĆ, J., GRGIĆ, Z. (2005.): Ekonomika integrirane proizvodnje maslina. Pomologia Croatica Vol. 11 (1-2).

SITO, S., ČMELIK, Z., STRIKIĆ, F., BILANDŽIJA, N., PREKALJ, B., KRALJEVIĆ, A. (2012.): Strojna sadnja masline pomoću GPS sustava i lasera. Pomologia Croatica Vol. 18 (1-4). 
M. Čagalj i F. Strikić: Ekonomska ocjena investicije podizanja nasada maslina na kršu. Rezultati istraživanja melioracije ( 25 ha) terena u općini Tisno (Girića rat)

JELAVIĆ A., RAVLIĆ P., STARČEVIĆ A., ŠAMANOVIĆ J. (1993.): Ekonomika poduzeća. Ekonomski fakultet, Zagreb.

\section{Adresa autora - Author's address:}

Marin Čagalj,

e - mail: marin.cagalj@krs.hr

Institut za jadranske kulture i melioraciju krša,

Frane Strikić,

Institut za jadranske kulture i melioraciju krša,

Put Dulova 1, 21000 Split

Znanstveni centar izvrsnosti za bioraznolikost i molekularno oplemenjivanje bilja, Svetošimunska 25, 10000 Zagreb 
